\title{
The Effects of System Changes in Grazed Dairy Farmlet Trials on Greenhouse Gas Emissions
}

\author{
Tony van der Weerden ${ }^{1} *{ }^{\mathbb{C}}$, Pierre Beukes ${ }^{2}$, Cecile de Klein ${ }^{1}$, Kathryn Hutchinson ${ }^{3}{ }^{\mathbb{C}}$,

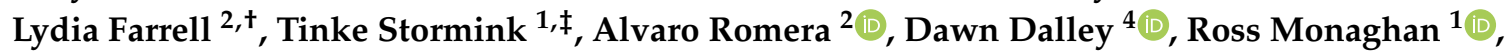 \\ David Chapman ${ }^{4}$, Kevin Macdonald ${ }^{2}$ and Robyn Dynes ${ }^{5}$
}

1 AgResearch, Invermay Agricultural Centre, Mosgiel 9053, New Zealand; cecile.deklein@agresearch.co.nz (C.d.K.); tinke.stormink@outlook.com (T.S.); ross.monaghan@agresearch.co.nz (R.M.)

2 DairyNZ Ltd., Private Bag 3221, Hamilton 3240, New Zealand; pierre.beukes@dairynz.co.nz (P.B.); lydia.farrell64@gmail.com (L.F.); alvaro.romera@dairynz.co.nz (A.R.); kevin.macdonald@xtra.co.nz (K.M.)

3 AgResearch, Grasslands Research Centre, Palmerston North 4410, New Zealand; kathryn.hutchinson@agresearch.co.nz

4 DairyNZ Ltd., Canterbury Agricultural \& Science Centre, Lincoln 7608, New Zealand; dawn.dalley@dairynz.co.nz (D.D.); david.chapman@dairynz.co.nz (D.C.)

5 AgResearch, Lincoln Research Centre, Lincoln 7674, New Zealand; robyn.dynes@agresearch.co.nz

* Correspondence: tony.vanderweerden@agresearch.co.nz; Tel.: +64-3-4899012; Fax: +64-3-4893739

+ Present Address: School of Agriculture and Environment, College of Sciences, Massey University, Palmerston North 4442, New Zealand.

$\ddagger$ Present Address: DuPont Industrial Biosciences, 2300 AE Leiden, The Netherlands.

Received: 15 October 2018; Accepted: 4 December 2018; Published: 7 December 2018

Simple Summary: Dairy farm system practices aimed at reducing nitrate leaching can also reduce emissions of the greenhouse gases methane and nitrous oxide. A study comparing 'current' and 'improved' grazed dairy system practices showed that 'improved' systems generally produced lower greenhouse gas emissions while milk production was maintained. The amount of feed eaten per hectare was the key driver of total greenhouse gas emissions per area, with 'improved' systems generally exhibiting lower total enteric methane and less $\mathrm{N}$ flowing through the herd.

Abstract: An important challenge facing the New Zealand (NZ) dairy industry is development of production systems that can maintain or increase production and profitability, while reducing impacts on receiving environments including water and air. Using research 'farmlets' in Waikato, Canterbury, and Otago (32-200 animals per herd), we assessed if system changes aimed at reducing nitrate leaching can also reduce total greenhouse gas (GHG) emissions (methane and nitrous oxide) and emissions intensity (kg GHG per unit of product) by comparing current and potential 'improved' dairy systems. Annual average GHG emissions for each system were estimated for three or four years using calculations based on the New Zealand Agricultural Inventory Methodology, but included key farmlet-specific emission factors determined from regional experiments. Total annual GHG footprints ranged between $10,800 \mathrm{~kg}$ and $20,600 \mathrm{~kg} \mathrm{CO}_{2} \mathrm{e} / \mathrm{ha}$, with emissions strongly related to the amount of feed eaten. Methane $\left(\mathrm{CH}_{4}\right)$ represented $75 \%$ to $84 \%$ of the total GHG footprint across all modelled systems, with enteric $\mathrm{CH}_{4}$ from lactating cows grazing pasture being the major source. Excreta deposition onto paddocks was the largest source of nitrous oxide $\left(\mathrm{N}_{2} \mathrm{O}\right)$ emissions, representing $7-12 \%$ of the total GHG footprint for all systems. When total emissions were represented on an intensity basis, 'improved' systems are predicted to generally result in lower emissions intensity. The 'improved' systems had lower GHG footprints than the 'current' system, except for one of the 'improved' systems in Canterbury, which had a higher stocking rate. The lower feed supplies and associated lower stocking rates of the 'improved' systems were the key drivers of lower total GHG 
emissions in all three regions. 'Improved' systems designed to reduced N leaching generally also reduced GHG emissions.

Keywords: environmental modelling; pasture systems; nitrous oxide; methane emissions; nitrate leaching

\section{Introduction}

Agriculture is responsible for $47.9 \%$ of total greenhouse gas (GHG) emissions in New Zealand (NZ) but contributions to national emissions of methane $\left(\mathrm{CH}_{4}\right)$ and nitrous oxide $\left(\mathrm{N}_{2} \mathrm{O}\right)$ are $86 \%$ and 95\%, respectively [1]. Dairy farms primarily emit two GHG: (1) $\mathrm{CH}_{4}$ from enteric fermentation in the cow rumen, and (2) $\mathrm{N}_{2} \mathrm{O}$ arising mainly from denitrification of urinary nitrogen $(\mathrm{N})$ in the soil and nitrogen fertiliser application. Methane emissions from dairy cattle have increased $130 \%$ from 1990 to 2015 [1]. In 2015, enteric $\mathrm{CH}_{4}$ was the major contributor (73\%) while $\mathrm{N}_{2} \mathrm{O}$ from agricultural soils represented $21 \%$ of total GHG emissions from the agricultural sector [1]. The main drivers for this change are a doubling of the national dairy cow population since 1990 [2] and an increase in the application of synthetic $\mathrm{N}$ fertiliser $(>600 \%)$ over this same period [1]. In New Zealand, dairy cows graze ryegrass-dominant pastures, of which perennial ryegrass (Lolium perenne) is the major species, with supplements (e.g., maize silage, barley grain) typically less than $100 \mathrm{~g} / \mathrm{kg}$ of feed intake. Cows typically calve at the end of winter (i.e., July-September) and are milked for 8-10 months [3]. Similar pasture-based grazing systems for dairy cows are used in Australia [4,5] and Ireland [6].

An important challenge facing the NZ dairy industry, and globally, is to develop farm systems that can maintain or increase production (to meet increasing population demand) and profitability, while reducing impacts on receiving environments including water and air [7-9]. Various hypotheses have been advanced on changing dairy farm systems to reduce their environmental impact. Lowering stocking rate can result in more feed per cow, resulting in better-fed cows with more production per cow [3]. Fewer cows with better feed conversion efficiency could mean less feed is required for maintenance and more is converted into product. If cow genetic merit can be improved at the same time then these lower-stocked, well-managed systems can produce the same amount of product per hectare as higher-stocked systems [10]. The lower-stocked system will require less feed per area and, therefore, reduce the amount of $\mathrm{N}$ consumed and excreted by the herd. Nitrogen leaching will be reduced since the amount of urinary $\mathrm{N}$ deposited onto pasture is a major source of nitrate leaching [11]. Also, with lower feed intake from the smaller, more efficient herd it can be expected that the amount of enteric $\mathrm{CH}_{4}$ emitted will be reduced [3].

A reduction in $\mathrm{N}$ fertiliser use will usually reduce $\mathrm{N}$ leaching [12,13] and $\mathrm{N}_{2} \mathrm{O}$ losses from soils [14]. Less fertiliser will reduce the total amount of pasture grown, and also assist in a small reduction in the total $\mathrm{N}$ concentration of the herbage $[4,15]$ and, therefore, reduce the amount of $\mathrm{N}$ flowing through the stock, and excreted as urinary and dung $\mathrm{N}$. Reducing $\mathrm{N}$ fertiliser can be achieved through optimising its use, by targeting $\mathrm{N}$ application to pastures that have the greatest yield potential and to paddocks displaying signs of deficiency (yellowing and poor performance), rather than whole-farm $\mathrm{N}$ applications [16]. There is also the possibility of some compensation from less fertiliser through improved clover vigour and soil health resulting in greater natural $\mathrm{N}$ fixation $[17,18]$.

Other strategies for reducing environmental impacts of dairy farm systems include improved reproductive performance of the herd, which results in less involuntary culling and lower replacement rates (reviewed in [19]). Replacements produce $\mathrm{CH}_{4}$ and urinary $\mathrm{N}$ without contributing to milk production [20]. Greater use of high energy/low $\mathrm{N}$ feed (grain or forage) will reduce total urinary $\mathrm{N}$ excreted through lowering $\mathrm{N}$ intake [21] and improve the energy intake when pasture growth or pasture quality is low. This strategy also dilutes the effect of excess crude protein supplied by the pasture [22]. Off-paddock facilities can be used to reduce $\mathrm{N}$ returns to pasture during periods of 
low $\mathrm{N}$ utilisation and in turn decrease the risk of $\mathrm{N}$ leaching in winter and spring [23]. In addition, off-paddock facilities protect wet pasture from treading damage [24,25].

Farmlet systems trials (Pastoral 21-Phase 2 (P21), [26,27]) were run over a five-season period from 2011 to 2016 with the aim of developing industry-accessible, adoptable, system-level solutions for profitably increasing production while reducing $\mathrm{N}$ leaching [7]. Four dairy regions were used to provide contrasting challenges to dairy production due to different soil types, climates and local management practices. 'Improved' dairy systems for each region were initially developed to improve water quality outcomes via strategic changes to the current system. Some of these changes were recognised to also deliver reduced emissions of GHG whilst maintaining or increasing milk production and profitability [3]. The key changes included:

1. Using fewer, higher producing, cows

2. Smaller $\mathrm{N}$ fertiliser inputs

3. Lower herd replacement rate

4. Greater use of high energy/low $\mathrm{N}$ feed

5. Using off-paddock facilities to reduce the time cows spend on pasture (or on forage crops).

These five components were used to design the P21 farmlet systems trials with all or some of them applied to the 'improved' system in each location. Here, we examine whether 'improved' dairy systems designed to reduced N leaching also reduce GHG emissions. The effects of these system changes, or 'stacked mitigation options', are evaluated for total GHG emissions and emissions intensity (kg GHG per kg milksolids) by comparing 'current' and 'improved' dairy systems in these locations. This analysis tests the hypothesis that system changes aimed at reducing nitrate leaching will also reduce total greenhouse gas emissions and emissions intensity (kg GHG per kg milksolids). As part of this study, we determined which of the five key system changes delivered the greatest benefit.

\section{Methodology}

\subsection{Farmlets}

Relatively small-scale farms (farmlets ranging from 13 to 39 ha) were used to evaluate the system changes implemented in each of the three regions studied: the Waikato, Canterbury, and Otago (Table 1). These systems' studies ran from 2011 to 2015 in the Waikato, from 2011 to 2014 in Canterbury and from 2012 to 2015 in Otago.

In all systems, replacement stock were removed from the milking platform at birth and reared on support blocks, returning to the milking platform (pasture areas used for feeding milking cows) as rising 2-year old cows ( 22 months) before calving. In the modelling analysis, the support was included in the inventory calculations to ensure analysis of a complete system. $\mathrm{N}$ fertiliser applications on these blocks were assumed as $100 \mathrm{~kg} / \mathrm{ha} /$ year, based on expert opinion.

Details of the methodology used for estimating GHG emissions from the farmlets in all three regions can be found in the Supplementary File S1.

Table 1. 'Improved' system changes applied to farmlet system trials in Waikato, Canterbury, and Otago, New Zealand.

\begin{tabular}{cccccc}
\hline Region & $\begin{array}{c}\text { Fewer, Higher } \\
\text { Producing, } \\
\text { Cows }\end{array}$ & $\begin{array}{c}\text { Reduced N } \\
\text { Fertiliser } \\
\text { Inputs }\end{array}$ & $\begin{array}{c}\text { Reduced Herd } \\
\text { Replacement } \\
\text { Rate }\end{array}$ & $\begin{array}{c}\text { Greater Use of } \\
\text { High Energy/Low } \\
\text { N Feed }\end{array}$ & $\begin{array}{c}\text { Off-Paddock } \\
\text { Facilities }\end{array}$ \\
\hline Waikato & $\checkmark$ & $\checkmark$ & $\checkmark$ & $\checkmark$ & $\checkmark$ \\
$\begin{array}{c}\text { Canterbury } \\
\text { Otago }\end{array}$ & $\checkmark$ & $\checkmark$ & $\checkmark$ & $\checkmark$ & $\checkmark$ \\
\hline
\end{tabular}




\subsection{Waikato}

Two farmlets (13 ha each) were established at Scott Farm, Hamilton, New Zealand $\left(37^{\circ} 46^{\prime}\right.$ S, $175^{\circ} 22^{\prime}$ E) in June 2011 [7]. One system represented a current Waikato farm system ('current'), while the other employed technologies that might be required in improved farm systems ('improved') to reduce nitrate leaching. The 'improved' system was based on the concept of producing the same amount of milk per ha, but with the highest level of efficiency allowed by available technologies.

The stocking and replacement rates were lower for the 'improved' system (Table 2) and dairy cows with higher genetic merit were used (breeding worth of $\$ 170$ vs. \$90, respectively; Table 2). Reducing the stocking rate (SR) increased the annual feed allowance per cow which, combined with the higher genetic merit of cows in the 'improved' system, led to increased kg MS/cow. All this translated into a reduced need for $\mathrm{N}$ input, as less feed was required (i.e., producing the same with less).

An off-paddock facility was used in the 'improved' system where cows were removed from pasture onto a loafing pad for between 8 and $16 \mathrm{~h}$ daily from March until June (autumn until early winter). The loafing pad, also called a stand-off pad, was a plastic-lined area with wood chip bedding where cows could lie and where some of the dung and urine could be collected into the effluent system. The goal was to reduce $\mathrm{N}$ returns to pasture during a period of low $\mathrm{N}$ utilisation, thereby reducing $\mathrm{N}$ leaching risk during periods of drainage in winter/spring. All solid excreta deposited to the standoff pad was collected and stored until the following spring. A further goal was to protect wet pastures from treading damage.

The 'improved' farmlet cows were offered up to $3 \mathrm{~kg}$ DM/cow/day of low-crude protein grain to improve their energy intake when pasture growth or pasture quality was low. This strategy also had the aim of diluting excess crude protein supplied by the pasture. The 'current' system used bought in pasture and maize silage when DM requirements could not be met from its pasture growth.

Liquid effluent from the milking shed, collecting yard, and loafing pad was spread on the farmlets. Dung solids deposited in the milking shed and collecting yard were mechanically separated from the liquid phase for both systems. Emissions from these solids, and from solids captured by the loafing pad in the 'improved' system, were included in the GHG footprint calculations although these solids were exported from the farmlets to be spread in another location.

\subsection{Canterbury}

The Canterbury systems trial $\left(43^{\circ} 38^{\prime} \mathrm{S}, 172^{\circ} 28^{\prime}\right.$ E) examined the effect of two 'improved' farm systems with contrasting stocking rates of 3.5 and 5 cows/ha for 'improved(LOW)' and 'improved(HIGH)', respectively (Table 2; [16]). The farmlet size was 8.25 ha milking platform (MP) plus 2 ha wintering crop (WC) and 6.75 ha MP plus 1 ha WC, respectively.

The 'improved(LOW)' system used dairy cows with higher genetic merit than the 'improved(HIGH)' system (breeding worth of 140 vs. 133, respectively).

A combination of 'standard' ryegrass/white clover pasture and 'diverse' pasture (containing chicory, plantain, ryegrass, and clover) was incorporated into the 'improved(LOW)' system, in contrast to the 'improved(HIGH)' system that solely relied on 'standard' ryegrass/white clover pasture. In the 'improved(LOW)' system, non-lactating cows were wintered on forage kale and oats silage, while the 'improved(HIGH)' system cows were wintered on fodder beet and pasture silage. Cow replacement rates were the same for the two systems.

There was insufficient resourcing to include a 'current' system in Canterbury. However, a suitable farm nearby (Lincoln University Dairy Farm, 'LUDF') represented current Canterbury practices from 2011 to 2013, with a stocking rate of 4 cows/ha and non-lactating cows wintered on fodder beet [28]. Therefore, the LUDF was adopted as a representative 'current' system (Table 2), ensuring the methodology used for estimating the GHG footprint is consistent with the P21 farmlets. 
Table 2. Key management features of 'current' and 'improved' systems in Canterbury, Waikato, and Otago for assessing differences in, and key drivers of, GHG emissions from dairy systems. Estimated $\mathrm{N}$ leaching losses are also included $[7,16,27]$. HIGH and LOW $=$ high and low stocking rate; OPT $=$ optimised feeding and DCG = duration controlled grazing. See text for further descriptions of each systems.

\begin{tabular}{|c|c|c|c|c|c|c|c|c|}
\hline \multirow[b]{2}{*}{ System Features } & \multicolumn{2}{|r|}{ Waikato } & \multicolumn{3}{|c|}{ Canterbury } & \multicolumn{3}{|c|}{ Otago } \\
\hline & Current & Improved & $\begin{array}{c}\text { LUDF } \\
(2011-2013)\end{array}$ & $\begin{array}{l}\text { Improved } \\
\text { (HIGH) }\end{array}$ & Improved (LOW) & Current & $\begin{array}{c}\text { Improved } \\
\text { (OPT) }\end{array}$ & $\begin{array}{l}\text { Improved } \\
\text { (DCG) }\end{array}$ \\
\hline \multicolumn{9}{|c|}{ Milking platform } \\
\hline Stocking rate (cows/ha) & 3.2 & 2.6 & 4.0 & 5.0 & 3.5 & 3.0 & 2.8 & 2.8 \\
\hline Cow genetic merit $\left(\$ B W^{\#}\right)$ & 90 & 170 & 115 & 133 & 140 & 109 & 105 & 104 \\
\hline $\mathrm{N}$ fertiliser (kg N/ha/year) & 137 & 52 & 345 & 311 & 158 & 109 & 42 & 73 \\
\hline Replacement rate $(\%)$ & 22 & 18 & 23 & 23 & 23 & 23 & 18 & 18 \\
\hline High energy/low $\mathrm{N}$ feed & 0 & 0.24 (Grain t DM/cow/year) & $\mathrm{N} / \mathrm{A}$ & $\mathrm{N} / \mathrm{A}$ & $40 \%$ diverse pasture & $\mathrm{N} / \mathrm{A}$ & $\mathrm{N} / \mathrm{A}$ & $\mathrm{N} / \mathrm{A}$ \\
\hline Stand-off/housing & No & Yes & No & No & No & No & No & Yes \\
\hline \multicolumn{9}{|l|}{ Milksolids production * } \\
\hline (kg MS/ha/year) & 1193 & 1163 & 1870 & 2335 & 1785 & 964 & 931 & 949 \\
\hline (kg MS/cow/year) & 373 & 447 & 468 & 467 & 510 & 329 & 333 & 334 \\
\hline \multicolumn{9}{|c|}{ Wintering } \\
\hline Winter feed & On platform & On platform & $\begin{array}{l}\text { Fodder beet }+ \\
\text { Pasture silage }\end{array}$ & $\begin{array}{l}\text { Fodder beet }+ \\
\text { Pasture silage }\end{array}$ & Kale + Oat silage & Kale & Kale & $\mathrm{N} / \mathrm{A}$ \\
\hline $\mathrm{N}$ fertiliser (kg N/ha/year) & $\mathrm{N} / \mathrm{A}$ & N/A & 150 & 200 & 307 & 200 & 200 & N/A \\
\hline \multicolumn{9}{|c|}{ Total dairy system $\mathrm{N}$ loss } \\
\hline $\mathrm{N}$ leaching (kg N/ha/year) & 54 & 31 & 54 & 55 & 58 & $18^{\wedge}$ & $13^{\wedge}$ & $11^{\wedge}$ \\
\hline
\end{tabular}

LUDF: Lincoln University Dairy Farm; N/A: not applicable; ${ }^{\#}$ Breeding worth, \$ (May 2011); * Fat + Protein, measured in P21 study; ${ }^{\prime}$ assessed as estimated N leaching [27]. 


\subsection{Otago}

In Otago $\left(46^{\circ} 17^{\prime} \mathrm{S}, 169^{\circ} 43^{\prime} \mathrm{E}\right)$, three farmlet systems were used, consisting of 110 cows each (Table 2). Firstly, a 'current' system (37 ha milking platform) adopted management practices typical of the region. Secondly, a 'improved optimised' ('improved(OPT)') system (39 ha) focused on improved cow feeding without the need for additional spending on costly farm infrastructure, and thirdly, a improved duration-controlled grazing' ('improved(DCG)') system (39 ha) that utilised an off-paddock facility (loose-housed deep litter animal shelter) for housing cows periodically during winter, spring, and autumn [27].

There were several key differences between the 'current' and the two 'improved' systems. Both the 'improved(OPT)' and 'improved(DCG)' systems included a lower replacement rate (18\%) compared with $23 \%$ for the 'current' system, while $\mathrm{N}$ fertiliser applications were lower (42-73 kg N/ha/year) on the 'improved' system milking platforms compared with $109 \mathrm{~kg} \mathrm{~N} / \mathrm{ha}$ /year on the 'current' milking platform. In the 'improved(OPT)' system, pasture was supplemented with whole crop cereal silage during lactation. Short rotation (Italian) ryegrass pastures were also incorporated to better align pasture growth rates with cow feed demand.

In addition, optimised grazing management of winter brassica crops along with allocation of more feed per cow during winter months were used to improve body condition score (BCS) relative to the 'current' herd. A key management goal of this farmlet was to ensure that cows calved later, and in better condition, onto higher pasture covers to decrease the reliance on $\mathrm{N}$ fertiliser and supplements and better match pasture growth with cow demand.

In the 'improved(DCG)' system cows were removed from pasture overnight (12 h) in spring and autumn during the milking season, when critical soil moisture thresholds and grazing times were reached, to protect pastures from damage and, for autumn grazing, reduce urinary nitrogen return to soils prior to winter. Shorter grazing times in spring led to relatively large amounts of pasture requiring conservation as silage on this farmlet; combined with the relatively large amounts of effluent returned to pasture (more details below), $\mathrm{N}$ fertiliser inputs were lower compared with the control farmlet and ranged between 63 and $83 \mathrm{~kg} \mathrm{~N} / \mathrm{ha}$ /year.

During winter, cows were housed full time in a loose-housed deep litter animal shelter with the aim of improving BCS relative to the 'current' herd through improved utilisation of feed energy. The shelter $\left(767 \mathrm{~m}^{2}\right)$ initially contained $300 \mathrm{~m}^{3}$ of woodchip bedding material, with another $150 \mathrm{~m}^{3}$ added midway through the winter period. Adjacent to the shelter was a feeding apron. Non-lactating cows were housed in the animal shelter fulltime during the winter months (June until mid-August; see Table S2) until calving commenced.

Details of the manure management from the shelter use can be found in the Supplemental File. Briefly, liquid from excreta deposited in the animal shelter was collected in an effluent pond, whereas solid manure was removed from the shelter and stored prior to spreading onto the milking platform paddocks. Manure deposited onto the adjacent feeding apron was scraped and stored behind a weeping wall, with the liquid fraction contained in an effluent pond. Data collected by [29] were used for estimating the greenhouse gas emissions from the manure management.

\subsection{Greenhouse Gas Emissions}

Annual GHG emissions for each system were estimated for three (Canterbury and Otago) or four (Waikato) years, using calculations based on the New Zealand Agricultural Inventory methodology (NZAI; [1]). In brief, this methodology uses estimates of dry matter intake (DMI), $\mathrm{N}$ inputs, and $\mathrm{N}$ leaching losses, in combination with $\mathrm{CH}_{4}$ and $\mathrm{N}_{2} \mathrm{O}$ emission factors (EF). In this study a combination of NZAI emission factor values and $\mathrm{CH}_{4}$ and $\mathrm{N}_{2} \mathrm{O}$ emissions factors were used that were measured for key components of the milking platform or the wintering period for each system [30-32]. We used these targeted measurements to provide us with emission factor results for key components in the farmlets that we otherwise would not able to assess as the NZAI emission factors are not sufficiently disaggregated. For example, NZAI uses the same methane emission factor for all feeds and therefore 
cannot distinguish between different feed types. As some of the key changes in our 'improved' systems were related to different feed types, we used our targeted measurements to get more specific $\mathrm{CH}_{4}$ (and $\mathrm{N}_{2} \mathrm{O}$ ) emission factors for these feed types. Similarly, as NZAI uses only one manure management system (anaerobic lagoons), we conducted targeted measurements of key components of the manure management system for the South Otago farmlet that used an off-paddock facility to ensure we could capture any difference in emissions as a result of the off-paddock facility.

The GHG footprint boundary was limited to $\mathrm{CH}_{4}$ and $\mathrm{N}_{2} \mathrm{O}$ emissions, and excluded carbon dioxide $\left(\mathrm{CO}_{2}\right)$ emissions from fertiliser manufacturing and use, fuel use, electricity use, and infrastructure construction. This ensured the footprint aligned with the boundaries of the NZAI. The footprint included both on-farm and off-farm sources of $\mathrm{CH}_{4}$ and $\mathrm{N}_{2} \mathrm{O}$ emissions. On-farm sources included enteric $\mathrm{CH}_{4}$ from the milking platform and wintering paddocks, $\mathrm{N}_{2} \mathrm{O}$ from soils receiving $\mathrm{N}$ inputs and $\mathrm{CH}_{4}$ and $\mathrm{N}_{2} \mathrm{O}$ emissions derived from manure management. Off-farm sources included $\mathrm{N}$ fertiliser use for producing pasture for replacement stock, N-excreta deposited by replacement stock, enteric $\mathrm{CH}_{4}$ from replacement stock and $\mathrm{N}$ fertiliser used for growing crops and supplements.

In addition to farm-scale GHG footprints, key sources of emissions were separated to determine the impact of off-paddock facilities on GHG emissions by combining the sources of emissions that are influenced by the presence or absence of such a facility. These sources included (i) direct and indirect $\mathrm{N}_{2} \mathrm{O}$ emissions associated with excreta deposition onto paddocks, because removing cows from paddocks onto off-paddock facilities would directly influence the amount of excreta deposited onto paddocks, (ii) and $\mathrm{N}_{2} \mathrm{O}$ and $\mathrm{CH}_{4}$ emissions associated with manure collected, stored, and subsequently applied to land (i.e., manure management). Both off-paddock facilities included in this study were assessed, the loafing pad in Waikato and animal shelter in Otago.

All $\mathrm{CH}_{4}$ and $\mathrm{N}_{2} \mathrm{O}$ emissions were converted to $\mathrm{CO}_{2}$-equivalent emissions using the 100-year time horizon global warming potentials of $25 \mathrm{~kg} \mathrm{CO}_{2}$-equivalent per $\mathrm{kg} \mathrm{CH}_{4}$ and $298 \mathrm{~kg} \mathrm{CO}_{2}$-equivalent per $\mathrm{kg} \mathrm{N}_{2} \mathrm{O}$ [33]. Greenhouse gas footprints for each system were calculated on an area basis ( $\mathrm{kg} \mathrm{CO}$-equivalent per milking platform hectare; $\mathrm{kg} \mathrm{CO}_{2} \mathrm{e} / \mathrm{ha}$; Table 3) and intensity basis ( $\mathrm{kg} \mathrm{CO}$-equivalent per $\mathrm{kg}$ milksolids produced; $\mathrm{kg} \mathrm{CO}_{2} \mathrm{e} / \mathrm{kg}$ MS; Table 4). 
Table 3. Total emissions ( $\mathrm{kg}$ carbon dioxide equivalents per hectare of the milking platform $\left(\mathrm{kg} \mathrm{CO}_{2} \mathrm{e} / \mathrm{ha} \mathrm{MP}\right)$ calculated for nitrous oxide $\left(\mathrm{N}_{2} \mathrm{O}\right)$ and methane $\left(\mathrm{CH}_{4}\right)$ for improved farm systems tested on small-scale farms in three regions in New Zealand (Waikato, Canterbury, and Otago). HIGH and LOW = high and low stocking rate; $\mathrm{OPT}=$ optimised feeding and $\mathrm{DCG}=$ duration controlled grazing. See text for further descriptions of each systems. Note: may not sum to total due to rounding.

\begin{tabular}{|c|c|c|c|c|c|c|c|c|c|}
\hline & \multirow{3}{*}{ Source } & \multicolumn{2}{|c|}{ Waikato } & \multicolumn{3}{|c|}{ Canterbury } & \multicolumn{3}{|c|}{ Otago } \\
\hline & & Current & Improved & $\begin{array}{c}\text { LUDF } \\
(2011-2013)\end{array}$ & $\begin{array}{c}\text { Improved } \\
\text { (HIGH) }\end{array}$ & $\begin{array}{c}\text { Improved } \\
\text { (LOW) }\end{array}$ & Current & $\begin{array}{c}\text { Improved } \\
\text { (OPT) }\end{array}$ & $\begin{array}{c}\text { Improved } \\
\text { (DCG) }\end{array}$ \\
\hline & & 3.2 Cows/ha & 2.6 Cows/ha & 4 Cows/ha & 5 Cows/ha & 3.5 Cows/ha & 3 Cows/ha & 2.8 Cows/ha & 2.8 Cows/ha \\
\hline \multirow{7}{*}{$\mathrm{N}_{2} \mathrm{O}$} & Urine + dung & 1602 & 1012 & 2110 & 2309 & 1519 & 1229 & 1108 & 760 \\
\hline & Fertiliser & 390 & 150 & 1108 & 990 & 665 & 448 & 270 & 220 \\
\hline & Manure mgmt & 99 & 390 & 254 & 31 & 21 & 11 & 9 & 387 \\
\hline & $\mathrm{NH}_{3}$ volatilised & 320 & 288 & 632 & 442 & 308 & 250 & 202 & 220 \\
\hline & $\mathrm{NO}_{3}$ leached & 217 & 162 & 247 & 223 & 241 & 86 & 64 & 44 \\
\hline & Replacement stock & 285 & 189 & 346 & 676 & 460 & 329 & 246 & 249 \\
\hline & Total $\mathrm{N}_{2} \mathrm{O}$ & 2913 & 2191 & 4697 & 4671 & 3213 & 2353 & 1900 & 1879 \\
\hline \multirow{6}{*}{$\mathrm{CH}_{4}$} & Ent Ferm. Pasture & 8131 & 7044 & 9195 & 8965 & 8085 & 5752 & 5330 & 5493 \\
\hline & Ent Ferm. Supplement + Winter crop & 1079 & 1081 & 2601 & 4120 & 2235 & 1982 & 2175 & 1976 \\
\hline & Ent Ferm. Replacement stock & 1363 & 906 & 1541 & 2226 & 1558 & 1308 & 976 & 987 \\
\hline & Manure mgmt & 124 & 183 & 594 & 633 & 490 & 433 & 411 & 1127 \\
\hline & Total $\mathrm{CH}_{4}$ & 10,697 & 9214 & 13,931 & 15,944 & 12,368 & 9475 & 8892 & 9582 \\
\hline & Total $\mathrm{CO}_{2} \mathrm{e}(\mathrm{kg})$ & 13,610 & 11,405 & 18,628 & 20,615 & 15,582 & 11,827 & 10,792 & 11,461 \\
\hline
\end{tabular}


Table 4. Emissions intensity ( $\mathrm{kg}$ carbon dioxide equivalents per milksolids $\left(\mathrm{kg} \mathrm{CO}_{2} \mathrm{e} / \mathrm{kg} \mathrm{MS}\right)$ ) calculated for nitrous oxide $\left(\mathrm{N}_{2} \mathrm{O}\right)$ and methane $\left(\mathrm{CH}_{4}\right)$ for current and improved farm systems tested on small-scale farms in three regions in New Zealand (Waikato, Canterbury, and Otago). HIGH and LOW = high and low stocking rate; OPT $=$ optimised feeding and DCG = duration controlled grazing. See text for further descriptions of each systems. Note: may not sum to total due to rounding.

\begin{tabular}{|c|c|c|c|c|c|c|c|c|c|}
\hline & \multirow{3}{*}{ Source } & \multicolumn{2}{|c|}{ Waikato } & \multicolumn{3}{|c|}{ Canterbury } & \multicolumn{3}{|c|}{ Otago } \\
\hline & & Current & Improved & $\begin{array}{c}\text { LUDF } \\
(2011-2013)\end{array}$ & $\begin{array}{l}\text { Improved } \\
\text { (HIGH) }\end{array}$ & $\begin{array}{l}\text { Improved } \\
\text { (LOW) }\end{array}$ & Current & $\begin{array}{c}\text { Improved } \\
\text { (OPT) }\end{array}$ & $\begin{array}{l}\text { Improved } \\
\text { (DCG) }\end{array}$ \\
\hline & & $\begin{array}{c}1193 \mathrm{~kg} \\
\text { MS/ha MP }\end{array}$ & $\begin{array}{c}1164 \text { kg } \\
\text { MS/ha MP }\end{array}$ & $\begin{array}{c}1870 \mathrm{~kg} \\
\text { MS/ha MP }\end{array}$ & $\begin{array}{c}2335 \mathrm{~kg} \\
\text { MS/ha MP }\end{array}$ & $\begin{array}{c}1785 \mathrm{~kg} \\
\text { MS/ha MP }\end{array}$ & $\begin{array}{c}964 \mathrm{~kg} \mathrm{MS} / \mathrm{ha} \\
\text { MP }\end{array}$ & $\begin{array}{c}931 \mathrm{~kg} \mathrm{MS} / \mathrm{ha} \\
\text { MP }\end{array}$ & $\begin{array}{c}949 \mathrm{~kg} \mathrm{MS} / \mathrm{h} \\
\text { MP }\end{array}$ \\
\hline \multirow{7}{*}{$\mathrm{N}_{2} \mathrm{O}$} & Urine + dung & 1.3 & 0.9 & 1.1 & 1.0 & 0.9 & 1.3 & 1.2 & 0.8 \\
\hline & Fertiliser & 0.3 & 0.1 & 0.6 & 0.4 & 0.4 & 0.5 & 0.3 & 0.2 \\
\hline & Manure mgmt & 0.1 & 0.3 & 0.1 & $<0.1$ & $<0.1$ & 0.0 & 0.0 & 0.4 \\
\hline & $\mathrm{NH}_{3}$ volatilised & 0.3 & 0.2 & 0.3 & 0.2 & 0.2 & 0.3 & 0.2 & 0.2 \\
\hline & $\mathrm{NO}_{3}$ leached & 0.2 & 0.1 & 0.1 & 0.1 & 0.1 & 0.1 & 0.1 & $<0.1$ \\
\hline & Replacement stock & 0.2 & 0.2 & 0.2 & 0.3 & 0.3 & 0.3 & 0.3 & 0.3 \\
\hline & Total $\mathrm{N}_{2} \mathrm{O}$ & 2.4 & 1.8 & 2.5 & 2.0 & 1.8 & 2.4 & 2.0 & 2.0 \\
\hline \multirow{6}{*}{$\mathrm{CH}_{4}$} & Ent Ferm. Pasture & 6.8 & 6.1 & 4.9 & 3.8 & 4.5 & 6.0 & 5.7 & 5.8 \\
\hline & Ent Ferm. Supplement + Winter crop & 0.9 & 0.9 & 1.4 & 1.8 & 1.3 & 2.1 & 2.3 & 2.1 \\
\hline & Ent Ferm. Replacement stock & 1.1 & 0.8 & 0.8 & 1.0 & 0.9 & 1.4 & 1.0 & 1.0 \\
\hline & Manure mgmt & 0.1 & 0.2 & 0.3 & 0.3 & 0.3 & 0.4 & 0.4 & 1.2 \\
\hline & Total $\mathrm{CH}_{4}$ & 8.9 & 8.0 & 7.4 & 6.8 & 6.9 & 9.8 & 9.6 & 10.1 \\
\hline & Total $\mathrm{CO}_{2} \mathrm{e}(\mathrm{kg})$ & 11.3 & 9.8 & 9.8 & 8.8 & 8.7 & 12.3 & 11.6 & 12.1 \\
\hline
\end{tabular}




\section{Results and Discussion}

\section{1. $\mathrm{CH}_{4}$ Emissions}

\subsection{1. $\mathrm{CH}_{4}$ Emissions per Area $(\mathrm{kg} \mathrm{CO} 2 \mathrm{e} / \mathrm{ha})$}

Methane represented between $75 \%$ and $84 \%$ of the total GHG footprint across all farmlet systems, with emissions ranging from $8892 \mathrm{~kg} \mathrm{CO} 2 \mathrm{e} / \mathrm{ha}$ ('improved(OPT)', Otago) to 15,944 $\mathrm{kg} \mathrm{CO} 2 \mathrm{e} / \mathrm{ha}$ ('improved(HIGH)', Canterbury) (Table 3). This broad range reflects contrasting feed supplies (sum of pasture production and supplements brought onto the farm) available to support stocking rate (SR) across systems ranging from 2.6 cows / ha in the Waikato 'improved' system to a substantially greater SR of 5.0 cows/ha in the 'improved(HIGH)' system in Canterbury (Table 2).

The majority of the emissions were from enteric fermentation by cows grazing pasture during lactation. Greater use of pasture as a feed source in Waikato compared against Canterbury and Otago explains the greater contribution of pasture-derived $\mathrm{CH}_{4}$ via enteric fermentation, representing 60-62\% of the total GHG emissions (Table 3). Enteric $\mathrm{CH}_{4}$ from supplements was responsible for 8-10\% of the total footprint in Waikato. In contrast, pasture-derived $\mathrm{CH}_{4}$ emissions for Canterbury and Otago represented $44 \%$ to $52 \%$ of the total GHG emissions per hectare while $\mathrm{CH}_{4}$ from supplements and winter forage crops collectively contributed $14-20 \%$ of the total GHG footprint (Table 3).

In the Waikato, the 'improved' system produced 14\% lower $\mathrm{CH}_{4}$ emissions per hectare compared with the 'current' system, while in Canterbury the 'improved(LOW)' system produced 22\% lower $\mathrm{CH}_{4}$ emissions per hectare compared with the 'improved(HIGH)' system. These reductions were primarily driven by stocking rate, although the lower replacement rate in the 'improved' system in Waikato and lower $\mathrm{CH}_{4}$ from supplement and crop intake in the 'improved(LOW)' system in Canterbury also contributed to this reduction. In Otago, total $\mathrm{CH}_{4}$ emissions from the 'improved(OPT)' system were $6 \%$ lower than $\mathrm{CH}_{4}$ emissions from the 'current' system, primarily due to lower emissions via enteric fermentation during lactation. In contrast, the 'improved(DCG)' system emitted a similar amount of $\mathrm{CH}_{4}$ as the 'current' system, with reduced enteric fermentation on the milking platform and the lower emissions from replacement stock (via lower replacement rate) being balanced by a tripling of estimated $\mathrm{CH}_{4}$ emissions from manure storage and handling (Table 3).

\subsection{2. $\mathrm{CH}_{4}$ Emissions Intensity ( $\mathrm{kg} \mathrm{CO}_{2} \mathrm{e} / \mathrm{kg}$ MilkSolids)}

Milk production per unit area was relatively unaffected by farm system in the Waikato and Otago, whereas in Canterbury there was a substantial difference in $\mathrm{kg}$ MS/ha, with $1785 \mathrm{~kg}$ and $2335 \mathrm{~kg}$ and MS/ha being measured for the 'improved(LOW)' and 'improved(HIGH)' systems, respectively (Table 2).

When emissions were expressed on an intensity basis, the data showed $\mathrm{CH}_{4}$ emissions from the Waikato 'improved' system were $10 \%$ lower than from the 'current' system $(8.0 \mathrm{~kg}$ vs. $8.9 \mathrm{~kg} \mathrm{CO} 2 \mathrm{e} / \mathrm{kg}$ MS, respectively; Table 4). This was due to the reduced feed requirements per unit of area, and thus enteric $\mathrm{CH}_{4}$ emission, enabled by the planned increase in production efficiency (less, more efficient, cows). In Canterbury, milk production in the 'improved(LOW)' system was $24 \%$ lower, similar to the reduction in $\mathrm{CH}_{4}$ emissions. As a result, $\mathrm{CH}_{4}$ emission intensities were similar for the two systems (6.9 vs. $6.8 \mathrm{~kg} \mathrm{CO}_{2} \mathrm{e} / \mathrm{kg}$ MS for the 'improved(LOW)' and 'improved(HIGH)' systems, respectively; Table 4). In Otago, $\mathrm{CH}_{4}$ emissions intensity was similar for all three systems, with the 'current', 'improved(DCG)' and 'improved(OPT)' systems producing $9.8 \mathrm{~kg}, 10.1 \mathrm{~kg}$, and $9.6 \mathrm{~kg} \mathrm{CO} 2 \mathrm{e} / \mathrm{kg} \mathrm{MS}$, respectively (Table 4 ). 


\section{2. $\mathrm{N}_{2} \mathrm{O}$ Emissions}

\subsection{1. $\mathrm{N}_{2} \mathrm{O}$ Emissions per Area ( $\left.\mathrm{kg} \mathrm{CO} \mathrm{CO}_{2} \mathrm{e} / \mathrm{ha}\right)$}

Nitrous oxide represented between 16 and $25 \%$ of the total GHG footprint across all farmlet systems, with emissions ranging from $1879 \mathrm{~kg} \mathrm{CO}_{2} \mathrm{e} / \mathrm{ha}$ ('improved(DCG)', Otago) to $4671 \mathrm{~kg} \mathrm{CO}_{2} \mathrm{e} / \mathrm{ha}$ ('improved(HIGH)', Canterbury), reflecting the SR, which ranged from 2.8 cows/ha (OPT and DCG, Otago) to 5.0 ('improved(HIGH)', Canterbury) (Table 3).

Excreta deposition onto paddocks was the largest source of $\mathrm{N}_{2} \mathrm{O}$ emissions, representing 9-12\% of the total GHG footprint for all systems apart from 'improved(DCG)' in Otago, where this source represented only $7 \%$ of the total footprint. This latter system included removal of cows from paddocks when soils were wet, resulting in less excreta deposited onto soil. Nitrogen fertiliser use and emissions associated with replacement stock were the next most important sources of $\mathrm{N}_{2} \mathrm{O}$ emissions, where fertiliser represented between $1 \%$ and $4 \%$ of the total GHG footprint, while replacement stock represented $2 \%$ and $4 \%$ of the total GHG footprint.

\subsection{2. $\mathrm{N}_{2} \mathrm{O}$ Emissions Intensity ( $\mathrm{kg} \mathrm{CO}_{2} \mathrm{e} / \mathrm{kg}$ MilkSolids)}

In the Waikato, $\mathrm{N}_{2} \mathrm{O}$ emission intensity represented $1.8 \mathrm{~kg} \mathrm{CO}_{2} \mathrm{e} / \mathrm{kg}$ MS for the 'improved' system, which was $25 \%$ lower than the $2.4 \mathrm{~kg} \mathrm{CO}_{2} \mathrm{e} / \mathrm{kg} \mathrm{MS}$ calculated for the 'current' system. The main driver of the reduction was less $\mathrm{N}$ entering the farm system in the form of $\mathrm{N}$ fertiliser and supplements. The reduction in pasture growth resulted in less pasture eaten for the farm system, thus reducing the excreta return (Table 4). Higher annual pasture allowance per cow, higher BW cows and longer lactations meant more milk was produced per cow in the 'improved' system. When combined, these factors resulted in lower emissions intensity i.e., $\mathrm{kg} \mathrm{CO}_{2} \mathrm{e} / \mathrm{kg}$ milksolids in the 'improved' system than for the 'current' system (Table 4).

In Otago, a 19\% reduction in $\mathrm{N}_{2} \mathrm{O}$ emission intensity calculated for the 'improved(DCG)' system (from 2.4 to $2.0 \mathrm{~kg} \mathrm{CO} \mathrm{CO}_{2} \mathrm{e} / \mathrm{kg} \mathrm{MS}$ ) was primarily driven by lower $\mathrm{N}$ fertiliser use, which reduced GHG intensity by $0.3 \mathrm{~kg} \mathrm{CO} 2 \mathrm{e} / \mathrm{kg}$ MS. A further factor was the reduction in excreta deposition onto paddocks, achieved by removing cows for $12 \mathrm{~h}$ per day when soils were wet (autumn and spring) and full time in winter when cows were not lactating (Table S2). This management strategy accounted for a reduction of $0.5 \mathrm{~kg} \mathrm{CO}_{2} \mathrm{e} / \mathrm{kg} \mathrm{MS}$, which was slightly more than the increase in $\mathrm{N}_{2} \mathrm{O}$ emissions associated with additional manure management $\left(+0.4 \mathrm{~kg} \mathrm{CO}_{2} \mathrm{e} / \mathrm{kg} \mathrm{MS}\right)$. In Canterbury, emission intensity for the two 'improved' systems were similar, at $1.8-2.0 \mathrm{~kg} \mathrm{CO} \mathrm{CO}_{2} / \mathrm{kg} \mathrm{MS}$.

\subsection{Total GHG Footprint}

\subsubsection{GHG Emissions per Area ( $\left.\mathrm{kg} \mathrm{CO}_{2} \mathrm{e} / \mathrm{ha}\right)$}

Total GHG footprints range between 10,792 $\mathrm{kg}$ and 13,610 $\mathrm{kg} \mathrm{CO}_{2} \mathrm{e} / \mathrm{ha}$ for the Waikato and Otago, with 'improved' systems producing a lower GHG footprint. This was particularly evident in the Waikato, where the reduction was $16 \%$, while the reductions in footprint in the Otago farmlets were smaller, at 3\% and 9\% for the 'improved(DCG)' and 'improved(OPT)' systems, respectively. The emissions from the Canterbury systems were greater compared with other the regions, at 15,582 and 20,615 $\mathrm{kg} \mathrm{CO}_{2} \mathrm{e} / \mathrm{ha}$ for the 'improved(LOW)' and improved(HIGH)' systems, respectively (Table 3). Total GHG emissions from the Canterbury 'current' system, which was based on data collated from the nearby Lincoln University Dairy Farm (SR of 4 cows/ha), were 18,628 $\mathrm{kg} \mathrm{CO}_{2} \mathrm{e} / \mathrm{ha}$. The emissions from the 'improved' systems were either 11\% higher (improved(HIGH)) or 16\% lower (improved(LOW)) than from this 'current' system. Combining regions, total GHG emissions/ha were strongly related to the amount of feed eaten/ha (Figure 1). 


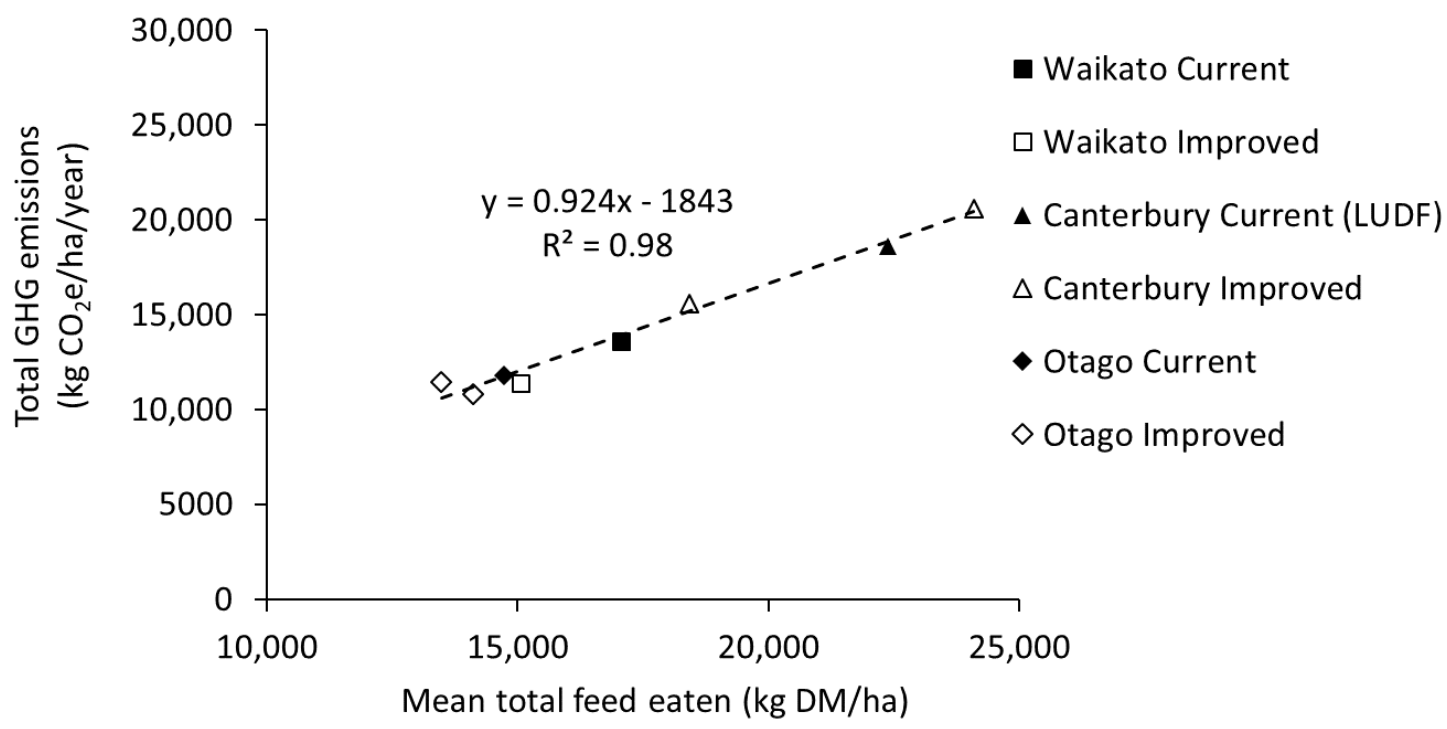

Figure 1. Relationship between mean total feed eaten ( $\mathrm{kg} \mathrm{DM} / \mathrm{ha})$ and total GHG emissions for 'current' and 'improved' systems trialled in three regions of New Zealand. Also included is the Canterbury 'current' system based on an updated analysis of the Lincoln University Dairy Farm (LUDF) system (P. Beukes, pers. comm.).

The Canterbury systems had the largest contrast in feed eaten (18,400 vs. $24,100 \mathrm{~kg} \mathrm{DM} / \mathrm{ha})$, resulting in the largest difference in GHG emissions per hectare (15,582 vs. $20,615 \mathrm{~kg} \mathrm{CO}_{2} \mathrm{e} / \mathrm{ha}$; Table 3). Emissions from the LUDF 'current' system [28], were similar to the 'improved(HIGH)' system, at 18,628 $\mathrm{kg} \mathrm{CO}_{2} \mathrm{e} / \mathrm{ha}$. However, this 'current' system produced $1870 \mathrm{~kg} \mathrm{MS} / \mathrm{ha}$, which was substantially less than the milk production of the 'improved(HIGH)' system ( $2335 \mathrm{~kg}$ MS/ha; Table 2).

Inclusion of off-paddock facilities in the Waikato and Otago 'improved' systems resulted in a decrease in excreta deposited onto paddocks and an increase in the amount of manure that required active management (see Table S4). To assess the impact of off-paddock facilities on GHG emissions, direct and indirect $\mathrm{N}_{2} \mathrm{O}$ emissions associated with excreta deposition onto paddocks and $\mathrm{N}_{2} \mathrm{O}$ and $\mathrm{CH}_{4}$ emissions associated with manure management were collated. Attempting to present these emissions on a per area basis can be difficult to interpret, given these facilities are farm structures; therefore, emissions have been calculated and presented as $\mathrm{kg} \mathrm{CO}_{2} \mathrm{e} / \mathrm{cow} /$ year. Our analysis showed that using an off-paddock facility results in a decrease in emissions per cow from excreta deposited onto paddocks, but this was more than offset by an increase in emissions per cow from manure management, resulting in a net increase in GHG emissions (Figure 2). The degree of the increase in emissions was dependent on the extent of the facility's use. For instance, the loafing pad in Waikato increased manure/excreta-related GHG emissions by $10 \%$ while the off-paddock facility in Otago led to a $35 \%$ increase in associated emissions per cow (Figure 2).

In order to assess the potential impact of adopting 'site-specific' rather than 'NZ-default' EF values on the calculated GHG emissions, we compared our results to those calculated when adopting the EF values from the NZ inventory methodology (results not shown). Adopting the NZ-default EF values had very limited impact on the relative difference in emissions between 'current' and 'improved' systems. For Waikato, the reduction in emissions remained at $16 \%$. For Canterbury, the increase in GHG emissions from 'current to 'improved(HIGH)' changed from $7 \%$ (site-specific EFs) to $8 \%$ (NZ-default EFs). The decrease in GHG emissions from 'current' to 'improved(LOW)' changed from $18 \%$ to $19 \%$. In Otago, using the NZ-default EF values did not impact on the relative difference between the 'current' and 'improved(OPT)', but it did slightly affect the result for 'improved(DCG)'. When using the site-specific EF values that were based on experimental results, a 3\% reduction in total GHG emissions was calculated. However, adopting the inventory approach resulted in a $1 \%$ 
reduction in GHG emissions between these two systems. This is most likely due to the fact that the NZ inventory methodology only includes the manure management system 'anaerobic lagoons', as this system is applicable to the vast majority of NZ dairy systems. However, given that the manure management system of the 'improved(DCG)' system is very different to the 'anaerobic lagoon' system, we believe the calculations based on the site-specific EF values are more accurate and realistic. Our study, therefore, represents the GHG footprint of dairy systems adopting 'current' and 'improved' management practices, estimated using the NZ inventory approach combined with site specific EF values where appropriate.

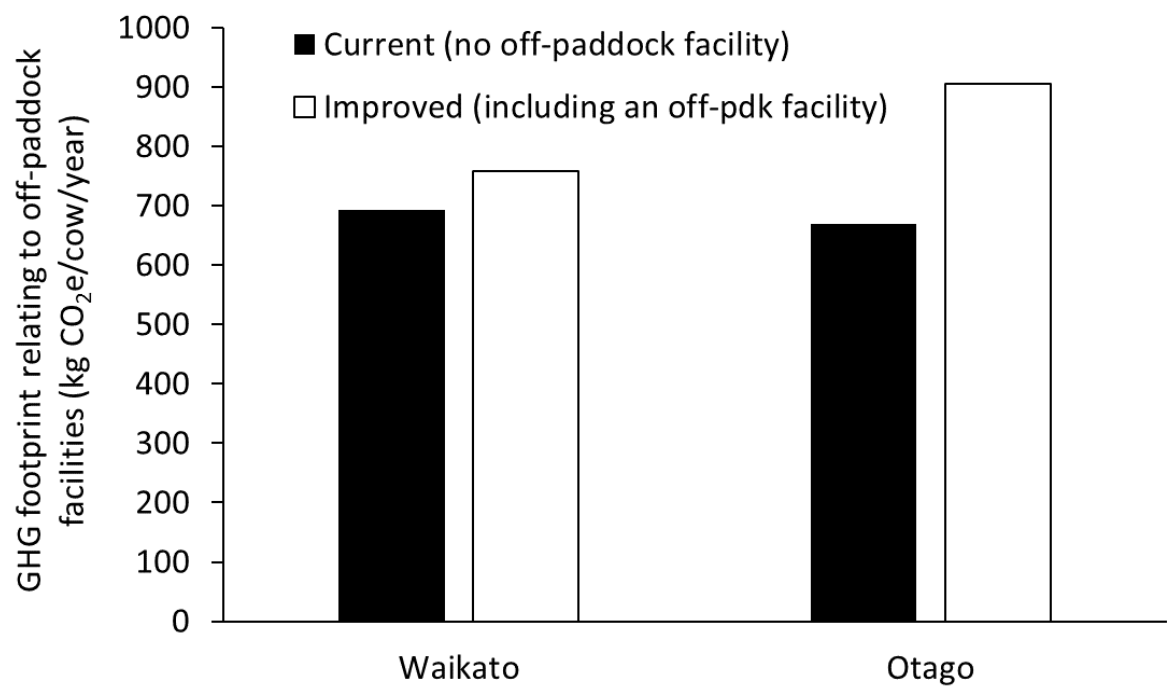

Figure 2. Effect of off-paddock facilities on net greenhouse gas emissions $\left(\mathrm{kg} \mathrm{CO}_{2} \mathrm{e} / \mathrm{cow} /\right.$ year $)$ associated with $\mathrm{N}_{2} \mathrm{O}$ from excreta deposition onto paddocks, and $\mathrm{N}_{2} \mathrm{O}$ and $\mathrm{CH}_{4}$ emissions from manure management.

\subsubsection{GHG Emissions Intensity ( $\mathrm{kg} \mathrm{CO}_{2} \mathrm{e} / \mathrm{kg}$ MilkSolids)}

When total emissions were represented on an intensity basis, emissions ranged from $8.7 \mathrm{~kg}$ to $12.3 \mathrm{~kg} \mathrm{CO} 2 \mathrm{e} / \mathrm{kg}$ MS. The 'improved' systems in all three regions produced lower GHG emission intensities, with reductions of $13 \%, 11-12 \%$, and $6 \%$ being calculated for 'improved' systems in Waikato, Canterbury, and Otago (OPT), when compared with the corresponding 'current' systems (Table 4). In most cases, the lower GHG intensities were largely a result of management practices such as reduced $\mathrm{N}$ fertiliser use and lower replacement rates lowering GHG emissions from the 'improved' system, because the difference in MS production between 'improved' and 'current' systems was small (Figure 3). For the 'improved(HIGH)' system in Canterbury, lower GHG intensities were largely a result of higher MS production, rather than reduced inputs. The 'improved(DGC)' system in Otago, based around standing cows off wet paddocks, and wintering cows in an animal shelter, produced a small reduction (2\%) in the GHG emissions intensity due to increased emissions from manure management, as shown above. Across all regions, total GHG emissions/ha were strongly related to amount of milk produced/ha (Figure 3). Analysis of the data, determined by comparing a single regression model with a combined model that included system type as a treatment, showed there was no significant difference in the 'current' vs. 'improved' systems $(p>0.05)$. The lack of significance was possibly due to the relatively small dataset, as the results showed lower GHG emissions for the same MS production from the 'improved' systems compared to the 'current' systems.

We compared our GHG emission intensity results with Gerber et al. [34], which presents $\mathrm{N}_{2} \mathrm{O}$ and $\mathrm{CH}_{4}$ emissions intensities from dairy cattle systems in 155 countries. For the comparison, we converted our results from $\mathrm{kg}$ MS to $\mathrm{kg}$ of fat and protein corrected milk (FPCM; [34]). The NZ dairy cattle systems modelled in our study produced between 4200 and $6700 \mathrm{~kg}$ FPCM per year, with $\mathrm{CH}_{4}$ emissions of 
between 0.6 and $0.8 \mathrm{~kg} \mathrm{CO} 2 \mathrm{e}$ per $\mathrm{kg}$ FPCM and $\mathrm{N}_{2} \mathrm{O}$ emissions of between 0.1 and $0.2 \mathrm{~kg} \mathrm{CO}_{2} \mathrm{e}$ per $\mathrm{kg}$ FPCM. Our results therefore compared well with those presented by Gerber et al. [34] for moderate to high intensity production systems.

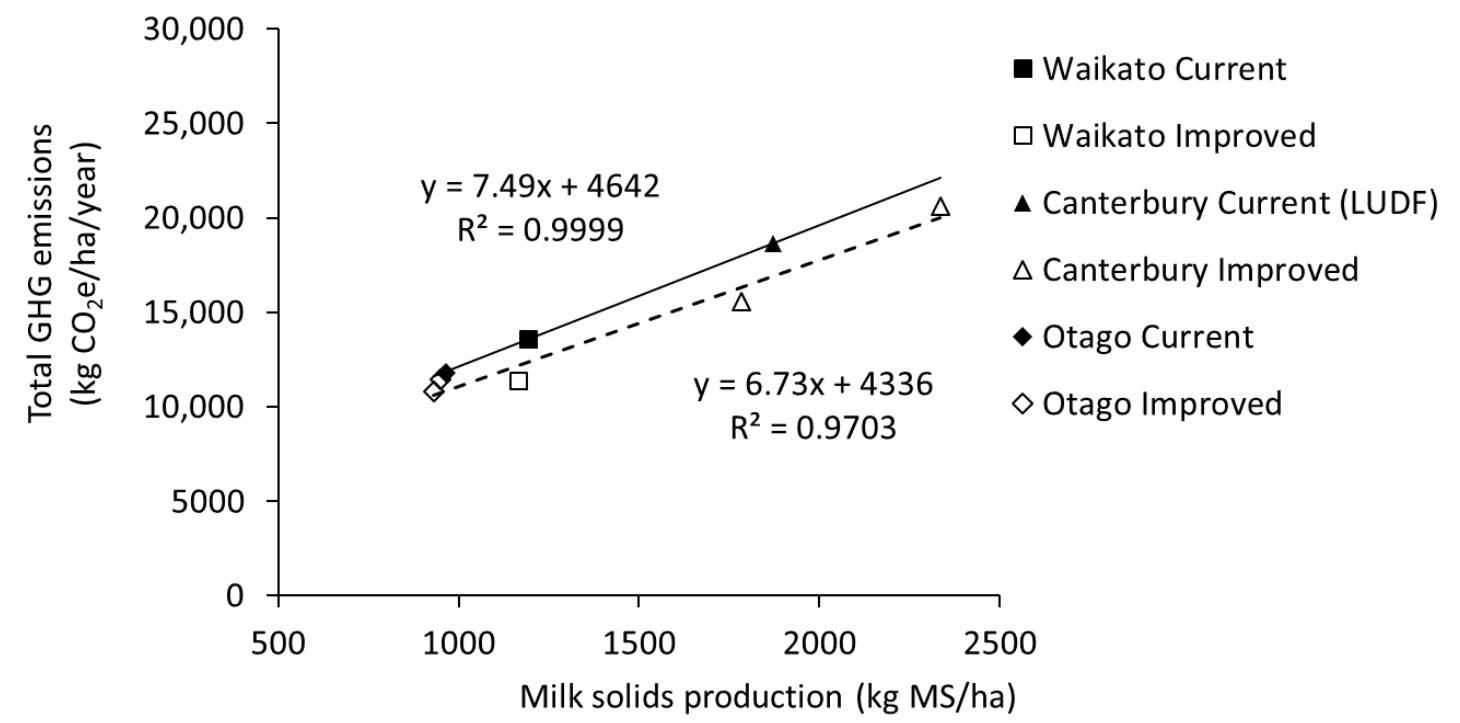

Figure 3. Relationship between milk production (kg MS/ha) and total GHG emissions for 'current' and 'improved' systems trialled in three regions of New Zealand. Also included is the Canterbury 'current' system based on an updated analysis of the Lincoln University Dairy Farm (LUDF) system (P. Beukes pers. comm.). There was no significant difference in the regression models.

\subsection{General Discussion}

Lower total GHG emissions, albeit not significant, were demonstrated in the 'improved' systems. Farm system trials are conducted at relatively large scales, making it challenging to replicate system treatments. Consequently, we have not been able to demonstrate 'significantly' lower GHG emissions from the 'improved' systems. However, our results do suggest that system changes aimed at reducing nitrate leaching can also reduce total greenhouse gas emissions and emissions intensity. The amount of feed eaten per ha was the key driver of total GHG emissions per area (Figure 1). Pasture-based dairy farming systems in the temperate environment of New Zealand have evolved to match seasonal pasture supply to the feed demand. The profitability and productivity of these systems is driven by stocking rate (cows/ha) which enables very high pasture utilisation and reasonable production per cow $[35,36]$. Both targeted nitrogen fertiliser application and supplement use contribute to feed supply (per hectare) and enable flexibility in stocking rate and profitability for many farming businesses. The amount of feed eaten per ha has an overriding effect on GHG emissions per ha because enteric $\mathrm{CH}_{4}$ from lactating cows is the major contributor to GHG emissions, as is the case with other pasture-based dairy systems $[8,37]$. Lower stocking rates are necessary when lower $\mathrm{N}$ inputs result in lower feed supply per ha (a function of $\mathrm{N}$ inputs including direct $\mathrm{N}$ fertiliser use for on-farm pasture production and off-farm supplement production). It has been shown that lower $\mathrm{N}$ inputs reduce farm-gate $\mathrm{N}$ surplus and thus the potential risk of $\mathrm{N}$ losses to the environment e.g., $[7,38]$. Others have also observed this relationship through measurements [39,40] and modelling [41]. Limiting the amount of $\mathrm{N}$ brought into a farm system as $\mathrm{N}$ fertiliser and supplements will reduce $\mathrm{N}$ intake and excretion by the herd, depositing less urinary $\mathrm{N}$ onto paddocks, and ultimately reducing $\mathrm{N}_{2} \mathrm{O}$ emissions. When combined with having cows with greater genetic merit (in the Waikato study), an increased feed conversion efficiency meant less feed was required for the herd for maintenance and more feed converted into product, resulting in lower feed requirements but similar milk production per hectare. Previous modelling $[3,42,43]$ showed that the combination of reduced stocking rates and high genetic merit 
cows consistently reduced total GHG emissions and emissions intensity, but with inconsistent impacts on milk production. The Waikato 'improved' system presents an example of a future vision, with minimal sacrifice of production per hectare $(2 \%)$ whilst demonstrating reductions in GHG emissions (by $16 \%$ and $13 \%$ when expressed on an area or emissions intensity basis, respectively) and $\mathrm{N}$ leaching (by 40-50\%; [7]). As for the Waikato, the Canterbury and Otago 'improved' systems also required less fertiliser $\mathrm{N}$ input, which lowered $\mathrm{N}_{2} \mathrm{O}$ emissions. The 'improved (OPT)' system in Otago also produced a lower GHG emission intensity ( $6 \%$ reduction), however there was also a small decrease in MS production (3\% reduction). Estimated N leaching for this system was reduced by $23 \%$ [27], providing another example of how GHG emission and N loss reductions could be achieved, albeit not as substantially as found for the Waikato study.

Others have also demonstrated reduced on-farm GHG emissions with less $\mathrm{N}$ fertiliser use (e.g., [44]). A combination of reduced $\mathrm{N}$ fertiliser use and lower stocking rates has been shown to have the largest impact on GHG emissions [45,46]. Using a Life Cycle Assessment method, Basset-Mens et al. [47] assessed the eco-efficiency of three contrasting New Zealand dairy systems. These researchers concluded that GHG emissions per area and per unit product (i.e., intensity-based) was lowest with the least intensive system, where no $\mathrm{N}$ fertiliser was used and cow stocking rate was 2.3 per ha compared with more intensive systems supporting 3.0 and 5.2 cows per ha. Potential eutrophication of waterways was projected to follow a similar pattern, with the least intensive system having the smallest potential for impact on waterways [47].

Manure management impacted heavily on the GHG footprint associated with the 'improved(DCG)' system, resulting in a footprint similar to that of the Otago 'current' system (Table 4). This negated any benefits achieved from removing cows off wet paddocks.

Previous work by Garnsworthy [48] predicted that improving fertility levels and breeding management in dairy cows, and therefore reducing the number of heifer replacements required, could reduce methane emissions at a herd level by $10 \%$ to $11 \%$. In a modelling study by Beukes et al. [3], they estimated the contribution of the reduced replacement rate strategy to GHG reductions to be in the order of $5 \%$. In the two regions of this study where replacement rates decreased from 'current' to 'improved' (Waikato from 22\% to 18\%, and Otago from 23\% to 18\%), we estimated a reduction of 3\% to $4 \%$ in total GHG emissions from the 'current' system. The farmlet trials in the Waikato and Otago demonstrated the merit of lower herd replacement rates from the current New Zealand average of $22-23 \%$ [2] to c. $18 \%$ as an option for making modest reductions in total GHG emissions.

One of the Canterbury systems included a contrast of feed types, with the 'current' and 'improved(HIGH)' systems relying on standard ryegrass/white clover pasture swards on the milking platform while non-lactating cows were wintered on fodder beet and pasture silage. In contrast, $40 \%$ of the milking platform in the 'improved(LOW)' system consisted of diverse pasture containing chicory, plantain, ryegrass, and clover, with non-lactating cows wintered on forage kale and oat silage. Although the diverse pasture was modelled to produce lower $\mathrm{N}_{2} \mathrm{O} \mathrm{EF}_{3}$ values for deposited urine [30], the emission intensities associated with total $\mathrm{N}_{2} \mathrm{O}$ loss from dung and urine did not differ between the two systems (Table 4). This was partly due to the 'improved(LOW)' system including kale in the winter period, which had a higher $\mathrm{EF}_{3}$ value than the fodder beet crop grazed in the 'current' and 'improved(HIGH)' systems.

Given the potential benefits of fodder beet over kale, for both $\mathrm{CH}_{4}$ and $\mathrm{N}_{2} \mathrm{O}$ emissions, and the similar amounts of silage consumed (see Supplement A), substituting kale for fodder beet in the 'improved' system, may result in even lower total GHG emissions for the 'improved' system. A similar suggestion was presented by Chapman et al. [16] for $\mathrm{N}$ leaching. These authors concluded that if the Canterbury 'improved(LOW)' system incorporated a fodder beet winter crop (rather than kale), $\mathrm{N}$ leaching could be reduced by $25-28 \%$.

The Otago farmlet systems included the use of palm kernel expeller (PKE) in year 3 (Table S1; Supplement A). When averaged over the three years of the study, the use of PKE represented 1.9\%, $0.5 \%$, and $1.7 \%$ of the dry matter intake for the CON, OPT, and DCG systems, respectively. There 
have been recent concerns linking consequences of indigenous deforestation with palm oil production, which has placed pressure on restricting the use of PKE on NZ dairy farms [49]. Deforestation results in additional GHG emissions through land use change, among other impacts. While our study has focused solely on biological emissions (i.e., $\mathrm{N}_{2} \mathrm{O}$ and $\mathrm{CH}_{4}$ only) from dairy production, we have estimated the increase in total GHG emissions for the Otago systems when the carbon (C) footprint associated with the use of PKE is included. A recent study suggests a $C$ footprint of 0.506 $\mathrm{kg} \mathrm{CO}$-equivalents per $\mathrm{kg}$ PKE DM used on NZ dairy farms [50] - this value includes emissions due to land use change. Based on this value, the additional $C$ footprint from the use of PKE in the CON, OPT, and DCG systems in Otago averaged over three years was estimated to be 49, 12, and $43 \mathrm{~kg} \mathrm{CO} 2 \mathrm{e} / \mathrm{ha} /$ year, respectively. Compared to the biological emission-based footprint (Table 3), the inclusion of the LCA-based C footprint associated with PKE use represents an additional 0.4\%, $0.1 \%$, and $0.4 \%$, respectively. This additional footprint does not change the emission intensity values shown in Table 4 , as the increase was less than $<0.1 \mathrm{~kg} \mathrm{CO} 2 \mathrm{e} / \mathrm{kg}$ MS.

The New Zealand dairy industry aims to identify dairy systems that can maintain or increase production while reducing impacts on receiving environments including water and air [9]. As such, the 'improved' systems designed in this study included a package of measures that incorporated the best available knowledge to reduce impacts on water whilst maintaining or increasing productivity $[7,16,27]$. Improved systems will be more attractive to farmers if they deliver additional benefits such as reduced impact on water quality, or if a reduction in milk production is not associated with a reduction in profitability. Across the three regions, the implementation of stacked mitigation options aimed at reducing $\mathrm{N}$ leaching may have changed the relationship between MS and GHG emissions per hectare. While the analysis across regions showed no significant difference in the regression models describing milk production and GHG emissions for 'current' and 'improved' systems, probably due to the relatively small dataset, it does suggest a reduction in emissions intensity may be possible.

Our modelling suggests, for the systems examined here, total GHG emissions could be reduced by between $4 \%$ and $16 \%$. Given the New Zealand dairy industry plan to contribute to meeting this nation's 2030 emissions reduction target of 30\% below 2005 levels [51], our modelled reductions are relatively modest. These reductions are based on currently available management options and research into additional agricultural mitigation options is continuing to be an important focus for New Zealand [48]. This includes research into developing low-methane animals, methane vaccines and inhibitors, low GHG feeds, and novel nitrification inhibitors [52-54]. Increasingly 'improved' dairy systems modelled here, and future strategies identified through the current research efforts, will be essential options for farmers to meet social and regulatory requirements in New Zealand. Profitability and cost effectiveness of the 'improved' systems modelled here are yet to be explored.

\section{Conclusions}

Our analysis indicates that system changes aimed at reducing nitrate leaching can also reduce total greenhouse gas emissions and emissions intensity. The reduced feed supplies and associated lower stocking rates of the 'improved' farmlet systems evaluated here were the key drivers of lower total GHG emissions in all three regions. The main effects of these improved farmlet attributes were smaller total enteric methane emissions and less $\mathrm{N}$ flowing through the herd, which lowered $\mathrm{N}$ excretion and, therefore, direct and indirect $\mathrm{N}_{2} \mathrm{O}$ losses. A system with fewer cows with greater genetic merit contributed to greater milk production per cow per lactation, less N leaching, and lower GHG emission intensities. Smaller but important contributions to lowering emissions were made by dietary changes, e.g., introducing low-protein grain supplements, cereal silages, fodder beet winter feed, herb-containing ryegrass pastures, and by lowering herd replacement rates. Off-paddock facilities contributed to protecting wet soils and reducing $\mathrm{N}$ leaching, but resulted in pollution swapping and increased total GHG emissions per cow. Our results suggest that total GHG emissions can be 
reduced through lower-stocked systems, where individual cow performance is optimised through better feeding of high genetic merit animals to compensate for the lower stocking rates.

Supplementary Materials: The following are available online at http://www.mdpi.com/2076-2615/8/12/234/s1, Supplementary File S1.

Author Contributions: Conceptualization, C.d.K. and R.D.; Methodology, P.B., C.d.K, L.F., T.S. and T.v.d.W.; Validation, P.B., C.d.K., K.H. and T.v.d.W.; Investigation, D.C., D.D., K.M., A.R. and R.M.; Data Curation, P.B., D.D., L.F., T.S. and T.v.d.W.; Writing-Original Draft Preparation, P.B., C.d.K., R.D., K.H. and T.v.d.W.; Writing-Review \& Editing, P.B., D.C., D.D., C.d.K., R.D., K.M., A.R., R.M. and T.v.d.W.; Funding Acquisition, C.d.K. and R.D.

Funding: This research was funded by the New Zealand Agricultural Greenhouse Gas Research Centre (http:/ /www.nzagrc.org.nz) (project number 14-IFS8.2) and the Sustainable Land Management and Climate Change Fund (https:/ / www.mpi.govt.nz/funding-and-programs/farming/sustainable-land-management-andclimatechange-research-program/) (contract AGR131402) administered by the Ministry for Primary Industries (Wellington, New Zealand).

Acknowledgments: We thank Dave Clark, Chris Glassey, Chris Roach, Grant Edwards, David Stevens, and Andrew Wall for their involvement in the initial set up and on-going management decision making of these farm system studies. We also thank Alasdair Noble for assistance with statistical analysis. This work could not have been completed without permission to align with work conducted through the Pastoral 21 Programme (C10X1117), jointly funded by the Ministry of Business, Innovation and Employment (MBIE), DairyNZ Inc., Fonterra, Beef + Lamb New Zealand and the Dairy Companies Association of New Zealand.

Conflicts of Interest: The authors declare no conflicts of interest.

\section{References}

1. Ministry for the Environment. New Zealand's Greenhouse Gas Inventory 1990-2015; Publication Number: ME 1309; Ministry for the Environment: Wellington, New Zealand, 2017; p. 502, ISSN 1179-223X (electronic). Available online: http:/ /www.mfe.govt.nz/node/23304/ (accessed on 8 August 2017).

2. DairyNZ and LIC. New Zealand Dairy Statistics 2015-16. Available online: https:/ / www.dairynz.co.nz/ publications/dairy-industry/new-zealand-dairy-statistics-2015-16/ (accessed on 31 July 2017).

3. Beukes, P.C.; Gregorini, P.; Romera, A.J. Estimating greenhouse gas emissions from New Zealand dairy systems using a mechanistic farm model and inventory methodology. Anim. Feed Sci. Technol. 2011, 166-167, 708-720. [CrossRef]

4. Pembleton, K.G.; Rawnsley, R.P.; Turner, L.R.; Corkrey, R.; Donaghy, D.J. Quantifying the interactions between defoliation interval, defoliation intensity and nitrogen fertiliser application on the nutritive value of rainfed and irrigated perennial ryegrass. Crop Pasture Sci. 2017, 68, 1100-1111. [CrossRef]

5. Wales, W.J.; Kolver, E.S. Challenges of feeding dairy cows in Australia and New Zealand. Anim. Prod. Sci. 2017, 57, 1366-1383. [CrossRef]

6. Coffey, E.L.; Delaby, L.; Fleming, C.; Pierce, K.M.; Horan, B. Multi-year evaluation of stocking rate and animal genotype on milk production per hectare within intensive pasture-based production systems. J. Dairy Sci. 2018, 101, 2448-2462. [CrossRef] [PubMed]

7. Beukes, P.C.; Romera, A.J.; Gregorini, P.; Macdonald, K.A.; Glassey, C.B.; Shepherd, M.A. The performance of an efficient dairy system using a combination of nitrogen leaching mitigation strategies in a variable climate. Sci. Total Environ. 2017, 599-600, 1791-1801. [CrossRef]

8. O'Brien, D.; Geoghegan, A.; McNamara, K.; Shalloo, L. How can grass-based dairy farmers reduce the carbon footprint of milk? Anim. Prod. Sci. 2016, 56, 495-500. [CrossRef]

9. Clark, D.A.; Caradus, J.R.; Monaghan, R.M.; Sharp, P.; Thorrold, B.S. Issues and options for future dairy farming in New Zealand. New Zeal. J. Agric. Res. 2007, 50, 203-221. [CrossRef]

10. Beukes, P.C.; Romera, A.J.; Clark, D.A. Farming within limits—Can systems fundamentals be the key? N. Z. Soc. Anim. Prod. 2013, 74, 241-244.

11. McDowell, R.W.; Monaghan, R.M.; Dougherty, W.; Gourley, C.J.P.; Vibart, R.; Shepherd, M. Balancing water-quality threats from nutrients and production in Australian and New Zealand dairy farms under low profit margins. Anim. Prod. Sci. 2017, 57, 1419-1430. [CrossRef]

12. Ledgard, S.F.; Penno, J.W.; Sprosen, M.S. Nitrogen inputs and losses from clover/grass pastures grazed by dairy cows, as affected by nitrogen fertiliser application. J. Agric. Sci. Camb. 1999, 132, 215-225. [CrossRef] 
13. Wachendorf, M.; Büchter, M.; Trott, H.; Taube, F. Performance and environmental effects of forage production on sandy soils. II. Impact of defoliation system and nitrogen input on nitrate leaching losses. Grass Forage Sci. 2004, 59, 56-68. [CrossRef]

14. Davidson, E.A. The contribution of manure and fertilizer nitrogen to atmospheric nitrous oxide since 1860. Nat. Geosci. 2009, 2, 659-662. [CrossRef]

15. Shepherd, M.; Lucci, G. A review of the effect of autumn nitrogen fertiliser on pasture nitrogen concentration and an assessment of the potential effects on nitrate leaching risk. Proc. N. Z. Grassl. Assoc. 2013, 75, $197-202$.

16. Chapman, D.; Edwards, G.; Dalley, D.; Cameron, K.; Di, H.; Bryant, R.; Romera, A.; Clement, A.; Malcolm, B.; Curtis, J. Nitrogen leaching, production and profit of irrigated dairy systems using either low or high inputs of fertiliser and feed: The Pastoral 21 experience in Canterbury. In Science and Policy: Nutrient Management Challenges for the Next Generation; Currie, L.D., Hedley, M.J., Eds.; Occasional Report No. 30; Fertilizer and Lime Research Centre, Massey University: Palmerston North, New Zealand, 2017.

17. Ledgard, S.F.; Sprosen, M.S.; Penno, J.W.; Rajendram, G.S. Nitrogen fixation by white clover in pastures grazed by dairy cows: Temporal variation and effects of nitrogen fertilization. Plant Soil 2001, 229, 177-187. [CrossRef]

18. Egan, M.; Galvin, N.; Hennessy, D. Incorporating white clover (Trifolium repens L.) into perennial ryegrass (Lolium perenne L.) swards receiving varying levels of nitrogen fertilizer: Effects on milk and herbage production. J. Dairy Sci. 2018, 101, 3412-3427. [CrossRef] [PubMed]

19. Knapp, J.R.; Laur, G.L.; Vadas, P.A.; Weiss, W.P.; Tricarico, J.M. Invited review: Enteric methane in dairy cattle production: Quantifying the opportunities and impact of reducing emissions. J. Dairy Sci. 2014, 97, 3231-3261. [CrossRef]

20. Waghorn, G.C. Application of greenhouse gas mitigation strategies on New Zealand farms. In Proceedings of the International Conference, Livestock and Global Climate Change 2008, Hammamet, Tunisia, 17-20 May 2008.

21. Kebreab, E.; France, J.; Beever, D.E.; Castillo, A.R. Nitrogen pollution by dairy cows and its mitigation by dietary manipulation. Nutr. Cycl. Agroecosyst. 2001, 60, 275-285. [CrossRef]

22. Luo, J.; Ledgard, S.F.; de Klein, C.A.M.; Lindsey, S.B.; Kear, M. Effects of dairy farming intensification on nitrous oxide emissions. Plant Soil 2008, 309, 227-237. [CrossRef]

23. de Klein, C.A.M.; Ledgard, S.F. An analysis of environmental and economic implications of nil and restricted grazing systems designed to reduce nitrate leaching from New Zealand dairy farms. I. Nitrogen losses. N. Z. J. Agric. Res. 2001, 44, 201-215. [CrossRef]

24. Laurenson, S.; Houlbrooke, D.J.; Beukes, P.C. Assessing the production and economic benefits from preventing cows grazing on wet soils in New Zealand. J. Sci. Food Agric. 2016, 96, 4584-4593. [CrossRef]

25. van der Weerden, T.J.; Laurenson, S.; Vogeler, I.; Beukes, P.C.; Thomas, S.M.; Rees, R.M.; Topp, C.F.E.; Lanigan, G.; de Klein, C.A.M. Mitigating nitrous oxide and manure-derived methane emissions by removing cows in response to wet soil conditions. Agric. Syst. 2017, 156, 126-138. [CrossRef]

26. Chapman, D.; Clark, D.; Beukes, P.; Edwards, G.; Dalley, D.; Pinxterhuis, I.; Romera, A.; Shepherd, M.; Cameron, K.; Di, H.; et al. Strategies for increasing dairy systems research approach in two regions of New Zealand. Proc. Australas. Dairy Sci. Symp. 2012, 5, 417-421.

27. Shepherd, M.; Hedley, M.; MacDonald, K.; Chapman, D.; Monaghan, R.; Dalley, D.; Cosgrove, G.; Houlbrooke, D.; Beukes, P. A summary of key messages arising from the Pastoral 21 Research Programme. In Science and Policy: Nutrient Management Challenges for the Next Generation; Currie, L.D., Hedley, M.J., Eds.; Occasional Report No. 30; Fertilizer and Lime Research Centre, Massey University: Palmerston North, New Zealand, 2017.

28. Beukes, P.C. (DairyNZ, Hamilton, New Zealand). Personal communication, 2017.

29. Chrystal, J.; Monaghan, R.; Hedley, M.; Horne, D. Volumes and nutrient concentrations of effluent products generated from a loose-housed wintering barn with woodchip bedding. In Integrated Nutrient and Water Management for Sustainable Farming; Currie, L.D., Hedley, M.J., Eds.; Occasional Report No. 29; Fertilizer and Lime Research Centre, Massey University: Palmerston North, New Zealand, 2016.

30. Di, H.J.; Cameron, K.C.; Podolyan, A.; Edwards, G.R.; de Klein, C.A.M.; Dynes, R.; Woods, R. The potential of using alternative pastures, forage crops and gibberellic acid to mitigate nitrous oxide emissions. J. Soils Sediments 2016, 16, 2252-2262. [CrossRef] 
31. Jonker, A.; Scobie, D.; Dynes, R.; Edwards, G.; de Klein, C.; Hague, H.; McAuliffe, R.; Taylor, A.; Knight, T.; Waghorn, G. Feeding fodder beet decreased methane emissions from dry and lactating dairy cows in pastoral systems. Anim. Prod. Sci. 2017, 74, 145-147.

32. van der Weerden, T.J.; Styles, T.M.; Rutherford, A.J.; de Klein, C.A.M.; Dynes, R. Nitrous oxide emissions from cattle urine deposited onto soil supporting a winter forage kale crop. N. Z. J. Agric. Res. 2017, 60, 119-130. [CrossRef]

33. Forster, P.; Ramaswamy, V.; Artaxo, P.; Berntsen, T.; Betts, R.; Fahey, D.W.; Haywood, J.; Lean, J.; Lowe, D.C.; Myhre, G.; et al. Changes in atmospheric constituents and in radiative forcing. In Climate Change 2007: The Physical Science Basis; Contribution of Working Group I to the Fourth Assessment Report of the Intergovernmental Panel on Climate Change; Cambridge University Press: Cambridge, UK; New York, NY, USA, 2007; p. 996.

34. Gerber, P.; Vellinga, T.; Opio, C.; Steinfeld, H. Productivity gains and greenhouse gas emissions intensity in dairy systems. Livest. Sci. 2011, 139, 100-108. [CrossRef]

35. Dillon, P.; Roche, J.R.; Shalloo, L.; Horan, B. Optimising financial returns from grazing in temperate pastures. Utilisation of Grazed Grass in Temperate Animal Systems. In Proceedings of the Satellite Workshop, 20th International Grassland Congress, Cork, Ireland, 3-6 July 2005; pp. 131-147.

36. Macdonald, K.A.; Penno, J.W.; Lancaster, J.A.S.; Roche, J.R. Effects of stocking rate on pasture production, milk production and reproduction of dairy cows in pasture-based systems. J. Dairy Sci. 2008, 91, 2151-2163. [CrossRef] [PubMed]

37. Aguirre-Villegas, H.A.; Passos-Fonseca, T.H.; Reinemann, D.J.; Larson, R. Grazing intensity affects the environmental impact of dairy systems. J. Dairy Sci. 2017, 100, 6804-6821. [CrossRef]

38. Oenema, J.; Burgers, S.; Verloop, K.; Hooijboer, A.; Boumans, L.; Berge, H.T. Multiscale effects of management, environmental conditions, and land use on nitrate leaching in dairy farms. J. Environ. Qual. 2010, 39, 2016-2028. [CrossRef]

39. Humphreys, J.; O'Connell, K.; Casey, I.A. Nitrogen flows and balances in four grassland-based systems of dairy production on a clay-loam soil in a moist temperate climate. Grass Forage Sci. 2008, 63, 467-480. [CrossRef]

40. Monaghan, R.M.; Paton, R.J.; Smith, L.C.; Drewry, J.J.; Littlejohn, R.P. The impacts of nitrogen fertiliser and increased stocking rate on pasture yield, soil physical condition and nutrient losses in drainage from cattle grazed pasture. N. Z. J. Agric. Res. 2005, 48, 227-240. [CrossRef]

41. Beukes, P.C.; Scarsbrook, M.R.; Gregorini, P.; Romera, A.J.; Clark, D.A.; Catto, W. The relationship between milk production and farm-gate nitrogen surplus for the Waikato region, New Zealand. J. Environ. Manag. 2012, 93, 44-51. [CrossRef] [PubMed]

42. Dynes, R.A.; Smeaton, D.; Rhodes, A.P.; Fraser, T.J.; Brown, M.A. Modelling farm management scenarios that illustrate opportunities farmers have to reduce greenhouse gas emissions while maintaining profitability. N. Z. Soc. Anim. Prod. 2011, 71, 167-171.

43. Vibart, R.; Vogeler, I.; Dennis, S.; Kaye-Blake, W.; Monaghan, R.; Burggraaf, V.; Beautrais, J.; Mackay, A. A regional assessment of the cost and effectiveness of mitigation measures for reducing nutrient losses to water and greenhouse gas emissions to air from pastoral farms. J. Environ. Manag. 2015, 156, $276-289$. [CrossRef] [PubMed]

44. de Klein, C.A.M.; Monaghan, R.M.; Ledgard, S.F.; Shepherd, M. A system's perspective on the effectiveness of measures to mitigate the environmental impacts of nitrogen losses from pastoral dairy farming. In Meeting the Challenges for Pasture-based Dairying: Proceedings of the 4th Australasian Dairy Science Symposium, 31 August-2 September 2010; Edwards, G.R., Bryant, R.H., Eds.; Lincoln University: Christchurch, New Zealand, 2010; pp. 14-28.

45. Adler, A.A.; Doole, G.J.; Romera, A.J.; Beukes, P.C. Cost-effective mitigation of greenhouse gas emissions from different dairy systems in the Waikato region of New Zealand. J. Environ. Manag. 2013, 131, 33-43. [CrossRef] [PubMed]

46. Adler, A.A.; Doole, G.J.; Romera, A.J.; Beukes, P.C. Managing greenhouse gas emissions in two major dairy regions of New Zealand: A system-level evaluation. Agric. Syst. 2015, 135, 1-9. [CrossRef]

47. Basset-Mens, C.; Ledgard, S.; Boyes, M. Eco-efficiency of intensification scenarios for milk production in New Zealand. Ecol. Econ. 2009, 68, 1615-1625. [CrossRef] 
48. Garnsworthy, P.C. The environmental impact of fertility in dairy cows: A modelling approach to predict methane and ammonia emissions. Anim. Feed Sci. Technol. 2004, 112, 211-223. [CrossRef]

49. Vibart, R.; MacKay, A.; Wall, A.; Vogeler, I.; Beautrais, J.; Dalley, D. A farm-scale framework to assess potential farm- and regional-scale implications of removing palm-kernel expeller as a supplementary feed for dairy cows. Anim. Prod. Sci. 2017, 57, 1336-1342. [CrossRef]

50. Ledgard, S.; Falconer, S. Total Greenhouse Gas Emissions from Farm Systems with Increasing Use of Supplementary Feeds Across Different Regions of New Zealand. Report Prepared for the Ministry of Primary Industries; SLMACC-AGR30624; Milestone 12; 2015. Available online: https:/ / www.mpi.govt. $\mathrm{nz} /$ funding-and-programmes / farming/sustainable-land-management-and-climate-change-researchprogramme/sustainable-land-management-and-climate-change-slmacc-research-reports / (accessed on 14 November 2018).

51. United Nations Framework Convention on Climate Change. Intended Nationally Determined Contributions, New Zealand Submission to ADP 2015. Available online: http://www4.unfccc.int/submissions/ INDC/Published\%20Documents/New\%20Zealand/1/New\%20Zealand\%20INDC\%202015.pdf (accessed on 29 October 2018).

52. New Zealand Agricultural Greenhouse Research Centre. Highlights 2017. Available online: https://www. nzagrc.org.nz/knowledge,listing,457,nzagrc-highlights-2017.html (accessed on 2 November 2018).

53. Pastoral Greenhouse Gas Research Consortium. Research 2018. Available online: https:/ /www.pggrc.co.nz/ research (accessed on 2 November 2018).

54. Ministry for Primary Industries. Global Partnerships in Livestock Emissions Research, an International Research Fund in Support of the Global Research Alliance on Agricultural Greenhouse Gases 2016. Available online: https: / www.mpi.govt.nz/funding-and-programmes/farming/global-partnerships-in-livestockemissions-research/ (accessed on 2 November 2018).

(C) 2018 by the authors. Licensee MDPI, Basel, Switzerland. This article is an open access article distributed under the terms and conditions of the Creative Commons Attribution (CC BY) license (http:/ / creativecommons.org/licenses/by/4.0/). 